\title{
The Political Conduct of Imam Ridha WHile FaCing THE Revolts at The Time OF His Imamate
}

\author{
Hamid Reza Shojaeifard \\ University of Religion and Denominations, Qom, I. R. Iran

\section{Zahra Sajadi} \\ University of Religion and Denominations, Qom, I. R. Iran
}

\begin{abstract}
Imam is a guide, leader, navigator, successor of the Prophet and the Divine ambassador on the Earth, whose speech, action and authentication are authority and proofs for us. In fact, Imam is the true ideal for humanity in various aspects of worship, individual, social and political realms. While Imam's speech, actions and authentication is authority for us in matters of worship and jurisprudence, similarly they are proofs for us in the matters of governance and politics. Moreover, if we want to succeed in these grounds, we need to follow the infallible Imams and take their code of conduct as ideal for us.

This article seeks to examine the political conduct of Imam Ridha facing the revolts during the period of his Imamate, in order to set an example to Muslims in political affairs.
\end{abstract}

Keywords: infallibles, Imam Ridha, politics, islam, shia, conduct, revolt

\section{Introduction}

At the time of political rivalry between Caliph Amin and Caliph Ma'mun and Ma'mun struggling with internal problems, the Alawites

Corresponding author: shojaeifard@gmail.com

Corresponding author: zahra.sajady@gmail.com 
got a favorable chance to revolt against the Abbasids' oppressive rule. A few popular uprisings of that time were the revolt of Muhammad ibn Ibrahim ibn Tabataba, the revolt of Abu al-Saraya, Ibn Aftas, Zayd alNar, Ibrahim ibn Musa and Muhammad ibn Jafar. When we study the stand of Imam Ridha towards these revolts, we come to know that he did not oppose the revolt itself, but disagreed with the nature and time of these revolts.

Imam Ridha did not participate in the revolt of Ibn Tabataba on the day of revolt but postponed his presence to another day, which tells us that Imam agreed with the origin of the revolt but did not approve of the timing. His scolding Zayd and criticizing his actions tells us that Imam approved of the revolt itself.

On the other hand, it is important to study the understanding of the concept of Imamate and the nature of Ahl al-Bayt during the period of Imam Ridha, especially before Imam became the crown prince. It is clear from the historical evidence of the time of uprisings that the Alawites involved in these revolts had a different understanding of Imamate, which was other than the concept of Divine Imamate and the appointment of Imam by Allah only. We have this understanding because, at that time, the Alawites gathered around anybody who claimed to be an Imam and followed him. To the extent that the Alawites pledged to Muhammad Dibaj, who called himself Amir al-Mu'minin, they considered Imam Ridha equal to the rest of the Alawites in respect and dignity.

In such a situation, it was natural for Imam Ridha to refrain from any rebellious act to form a new government. In addition to this, other reasons were also involved, such as lack of military force, absence of active manpower and the heavy crackdown on Imams. In such a situation, the greater responsibility was spreading awareness amongst the people and the spiritual guidance of the community.

Although in some cases the Alawites gained relative victory in the beginning, later on all these rebellions faced a bitter defeat. Imam disagreed with the way the revolts took place, the lack of conscious leadership, dispersion and non-coordination between them, the lack of a clear plan, the leisure of the government concerning foreign issues and concentrating on internal issues resulting in a strong control of the Abbasids over the Alawites. These are the few important reasons that consequently led to the defeat.

Hopefully, some important discussion will take place in this paper regarding this topic. 


\section{Importance and Necessity of Research}

"The need of Imam", "research on Imam", "understanding Imam and Imamate", "knowing Imam and Imamate", and "finding Imam"5 - are the five steps of religious wayfaring and human contemplation. Every human being is required to walk this path to reach the highest level of human knowledge and religious contemplation. It is obvious that without the grace of the Almighty, one cannot attain knowledge nor can he walk the mystical path successfully. Because everything has its own way and the way to human perfection is entering through the "gate of Allah"6 then "knowledge of Allah" and "path of Allah" so that one can understand the stage of "proximity to Allah".

Achieving the level of 'Ind Allah - proximity to Allah, can only happen when a person follows his Imam in all realms of his life, such as his religious life, political life, social and individual lives.

One of the critical issues that came up after Prophet Muhammad and Imam Ali ibn Abi Talib was that Muslims stopped following the Imam of their time in political issues and this led to a certain oppression of the

1 "One day We shall call together all human beings with their (respective) Imams: 'those who are given their record in their right hand will read it (with pleasure), and they will not be dealt with unjustly in the least"' (Quran 17: 71). Accepting to live in a society and lead a social life cannot be imagined without leadership, because in order to identify the right path for the society a leader is needed. Actually, walking the road of success and prosperity is not possible without a guide and this is the very reason behind prophet hood and their successors (Makarim Shirazi 2001: XII/203).

2 Muslims must be certain about the Usul al-Din (Islamic principles), if not sure, they should reach the level of certainty (Subhani Tabrizi 2008: 114). Therefore, one has to acquire these principles on the basis of research based on rational reasoning and divine revelation.

3 When Imam Husain ibn Ali was asked about recognizing Imam, he said: "Do you know what the real knowledge is? It is the knowledge of the people that they have about the Imam of their time whose obedience upon them is obligatory" (Ibn Babiwayh 2006: I/9).

4 The Prophet of Islam says: "This issue (Islamic government) will not take place unless the twelve Imams have come and gone"(Majlisi 1983: XXXVI/266).

5 The Prophet Muhammad said: "For whom I'm the Mawla, Ali is his Mawla" (Hilali 1985: II/758).

6 Imam Ali ibn Abi Talib said: "I'm the eyes of Allah, I'm the hand of Allah, I'm the side of Allah, I'm the door of Allah" (Saffar 1984: I/61).

7 The Prophet Muhammad said: "I'm the city of knowledge and Ali is its door, whoever wants the knowledge should come through the door" (Ali ibn Musa al-Ridha 1986: 58).

8 It is narrated in Dua al-Nudba: "No reward do I ask of you for it but this: 'that each one who may take a (straight) Path to his Lord"' (Quran 25: 57). Verily they (Ahl al-Bayt) were the path to reach you and they were the way for your Ridwan (Ibn Mashhadi 1998: 578).

9 The level of 'Ind Allah is the proximity to Allah with firm belief in the position of Imamate. 
Infallible Imams and inability to form a government due to lack of friends and followers.

Later on, following the conspiracies of the enemies, this became a doubtful issue, thus the slogan that religion is separate from politics became a part of belief system. Subsequently, Muslims started to believe that Prophet Muhammad, Imams and religious scholars have nothing to do with political issues and they should only attend to the religious and jurisprudential matters. This condition lasted until Imam Khomeini returned to Iran from France and erased that misunderstanding and belief by forming the Islamic Republic of Iran and establishing the doctrine of Wilayat al-Faqih (the guardianship of the Islamic jurist).

\section{Fundamental Questions}

Studying the life of the people in the past in history books gives us some information about the people we did not see or meet, which leads to many questions and confusion. Scholars of the society are supposed to answer such ambiguities to free the minds of the readers from misleading doubts.

Therefore, we will point out several important questions here, and later on provide answers using authentic historical sources.

1. Why didn't Imam Ridha establish an Islamic government?

2. Why didn't Imam Ridha support the ruling government?

3. Was Imam Ridha in favor of or against the revolts?

4. Why did all of these revolts face a defeat in the end?

5. What was the opinion of Imam Ridha regarding these revolts?

\section{A Brief Note on the Life of Imam Ridha}

Ali ibn Musa al-Ridha (1 January 766 - 6 June 818) was the son of Imam Musa Kazim and Najmah Khatoon. He was the eighth Imam of the Twelver Shiites.

He was known as Abul-Hasan and his Imamate lasted for 20 years, which coincided with the end of Haroon al-Rasheed's reign and the beginning of the caliphate of Amin (four years) and early five years of the caliphate of Ma’mun Abbasi (Qomi 2000: III/1608).

Imam Ridha spent most of his life in his birthplace i.e. the city of Madinah, but in the year 816, Ma'mun Abbasi insisted and forcefully called Imam to Marw, the place of his caliphate. In Marw, Ma'mun compelled Imam to be- 
come the crown prince and in the year 818 Ma'mun poisoned Imam, which led to His martyrdom. The place where he was buried was later called Mashhad al-Ridha and today it is one of the important holy sites for Shiites.

Kulayni narrates from Yasir Khadim and Rayyan ibn Salt that, when Amin's rule ended and the government of Ma'mun was established, he wrote a letter to Imam Ridha and asked him to come to Khurasan. Imam made an excuse and refrained from migrating but Ma'mun insisted to an extent that Imam knew he had no choice, so he left Madinah (Kulayni 1987: II/407).

Sheikh Saduq quotes from Muawwal Sijistani that he says: "when a delegation arrived in Madinah to accompany Imam to Khurasan, I was there. Imam visited the holy shrine of the Prophet to bid farewell. I saw him repeatedly go in and come out of the shrine. I went to him, said Salam and inquired about this act. Imam replied: 'I'm leaving my grandfather and will die in a foreign land"' (Ibn Babiwayh 1999: II/217).

Moreover, when Imam Ridha wanted to leave for Khurasan he did not take his family members along. This, in itself, is a proof that Imam was not happy with this journey and had no high hopes of this migration.

Hasan ibn Ali Washsha says: "Imam told me: When they were ready to take me outside of Madinah, I gathered all of my family members and told them to cry loudly for me so that I could hear their voices. Then I distributed twelve thousand dinars amongst them and told them that I would not return" (Qomi 2000: III/1665).

Undoubtedly, from such instances, everyone who had a fair understanding and especially the Shiites who were in direct contact with the Imam understood that Imam was taken to Khurasan against his will. After rejecting the offer of Caliphate from Ma'mun, he offered Imam Ridha to become the crown prince. However, Imam did not accept this offer either. Nevertheless, once again Ma'mun insisted and threatened Imam with assassination and left Imam with no option other than to accept this offer.

Imam explained Ma'mun's intention from the meeting with the following words: "By such means you (Ma'mun) want people to say about me that Ali ibn Musa Ridha did not leave worldly attachments; instead, the world left him. Don't you all see how he accepted to become the crown prince in order to get to the caliphate?"

Ma'mun became angry after Imam refused the proposal of the caliphate and said: "You always force me to do things which I don't like and maybe you are not afraid of my might and power and consider yourself safe from my wrath. I swear upon God, become my crown prince or I will make you do it with force. You will do as I say or else I will kill you".

At last, with the following conditions Imam accepted his offer: 
I will not designate anybody in the government matters.

I will not remove anybody from any government position.

I will not make changes in the laws.

I will advise in government issued but will stay away.

This agreement was officially written and was signed by Imam Ridha and Ma'mun while many officials and famous people witnessed the event and it is narrated in many history books. Later, Ma'mun held a high profile meeting with his officials and courtiers. He told everyone to take off black clothes, which was the sign of Abbasids, and wear green instead, and asked people to swear allegiance to Imam Ridha (Fazlullah 2003: 135).

\section{Reasons behind Making Imam Ridha the Crown Prince}

Most of the governments who gained independence and the people participating in the revolts along with the leaders during this time were from the family of the Prophet (Ahl al-Bayt). Following the revolt of Abu al-Suraya, two of Imam's brothers got the governments of Yemen and Ahwaz. Every time they found an opportunity and suitable conditions, they would revolt against the ruling government. Anyhow, these uprisings continued until the time when Imam became the crown prince and even after that.

During the early years of Ma'mun's rule, they created many hurdles for the newly formed government. In most parts of the region under the Islamic government, Alawites invited people with the slogan "Al-Ridha min Al Muhammad" (Ridha from the family of Prophet Muhammad). The increase in these revolts was considered to be a major threat to the Abbasids' governance, and Ma'mun who saw the Abbasids' government under threat had no choice other than to call Imam from Madinah to Khurasan and entitle Imam as Al-Ridha and make him the crown prince to calm down the revolts of Alawites against him.

1) The threat posed by the revolts of Alawites was a serious issue for Abbasids' government. Therefore, in order to stay in power, Ma'mun decided to call Imam to Khurasan and make him the crown prince; this move to some extent helped in controlling the revolts of Alawites.

2) The presence of Imam Ridha, who was a descendant of the Prophet, helped Ma'mun to make his government legitimate, and he immediately ordered the Abbasids to take off black clothes and asked them to wear green ones. But, the clever act of Imam - conditioning the position of the crown prince - destroyed all conspiracies. The step taken by Ma'mun, the order to remove black clothes and wear green ones, clearly shows that he 
wanted to protect his position and attract the people of Khurasan. In later years, when Mamun achieved his goals, and he visited Baghdad, in the Nahrawan area, Abbasids gave him a warm welcome. They asked him to restore black clothes and remove green ones. He did so and again started wearing black clothes, which was an important sign for the Abbasids.

3) He constantly kept Imam under his watch and tried to reduce his public relations especially with the Alawites; he prevented Imam from social work and weakened Imam's social position.

4) Degrading Imam's dignity in the eyes of the people by blaming him for worldly desires and the desire to rule, although he was surely unsuccessful.

5) Attracting Imam's companions to the central government and then controlling them.

\section{The Revolts by Alawites during the Time of Imam Ridha}

After the conflict of Amin and Ma'mun, many Islamic cities were in a chaotic situation. Insecurity and anxiety prevailed over society. These drastic situations made it easy for the opposition to work against them to an extent that in Islamic territories people started talking about the end of Ma'mun's rule. Several important revolts by Alawites were:

\section{1) The Revolt of Muhammad ibn Ibrahim ibn Tabataba}

One of the revolts that took place during the time of Ma'mun and before Imam Ridha became the crown prince in the year 815 was the revolt of $\mathrm{Mu}$ hammad ibn Ibrahim, who was a grandson of Imam Ali ibn Abi Talib, along with Abu Suraya in Kufa.

A group of Arabs and Alawites were dissatisfied with Iranian tendencies of Ma'mun and were unhappy with his Iranian workers. This is why they joined forces with Muhammad ibn Ibrahim who was known as Ibn Tabataba. He started his revolt in Kufa with the slogan "Al-Ridha min Al Muhammad" (Ridha from the family of Prophet Muhammad), living according to the Book (Quran) and the Tradition. Surra ibn Mansur ibn Mansur Shaibani who was famous as Abu Suraya was given the leadership of the armed forces of this revolt. After the revolt, he became so strong in Kufa that he coined money in his own name.

This issue shows that he did not obey Imam because he wanted to gain power for himself. Abu Suraya's influence grew day by day and he even gained control over the nearby territories of Kufa. 
Conflicts between Amin and Ma'mun led to political instability that gave good opportunity to Alawites to start movements against the government in Iraq, Hijaz and Yemen. Perhaps the most dangerous one of them was the revolt of Abu Suraya (Majlisi 1983: VIII/161; Ibn al-Athir 1965: VI/306).

\section{2) The Revolt of Zaid ibn Musa (Zaid al-Naar)}

The rebellion of Zaid ibn Musa was one of important movements that took place at the time of Ma'mun. After the failure of Ibn Tabataba's revolt, some Alawites, who were actually followers of Ibn Tabataba, revolted and declared autonomy in the areas where they were based. Zaid revolted in Basra, and some of his family joined in his cause. According to Isfahani, "Zaid ibn Musa Alawi was called Zaid al-Naar (Zaid the Fire) because he burned the houses of members of the Abbasid family and their supporters in Basra. In addition, whenever a person in black clothes (supporters of Abbasids) was brought to him, he would burn him alive" (Qomi 2000: II/377; Ibn Kathir 1988: X/246).

\section{3) The Revolt of Ibrahim ibn Musa ibn Jafar}

When Ibrahim got the news about Abu Suraya and Alawites in Iraq, he soon left Mecca along with a few of his family members and went to Yemen in the year 816. In those days, Ma'mun appointed Ishaq ibn Musa as the governor of Yemen. Ibrahim ibn Musa overpowered them and gained control of the city and after a while Ma'mun sent Hamduh ibn Ali ibn Isa ibn Mahan to Yemen; a fierce battle took place between their forces and a lot of people were killed on both sides. Ibrahim adopted a violent way of governing and oppressed the people of Yemen in such a way they called him the "Butcher".

Ma'mun did everything to stop Ibrahim, especially because this was a Shia movement in Yemen, and it was also the continuation of the revolts of Ibn Tabataba and Abu Suraya, one of the most dangerous ones.

At last, Ma'mun ordered him to step down and he surrendered. It is also said that he fled to Mecca and was hiding there for one year. Later, he was captured and sent to prison. Some also said that Ma'mun pardoned him.

From this rebellion, we also learn that most of these movements were to topple the Abbasid rule and restore the rule of Alawites (Tabari 1967: VIII/536).

\section{4) The Revolt of Zuhur ibn Aftas in Madina}

During the time of Ma'mun, in the year 815, Husain ibn Hasan ibn Ali ibn Husain ibn Ali, famously known as Ibn Aftas, started his movement in Madina. In the beginning, he invited people towards Ibn Tabataba, but after 
his death in 816 , he declared his Imamate and gathered people around him. This is the proof of him not obeying Imam Ridha.

He then travelled to Mecca and joined the people while they were in Mina. When he entered Mecca, he removed the covering of the holy Ka'ba and covered it with two pieces of silk cloth, which Abu Suraya had given to them. On this cloth, it was written, "Asfar ibn Asfar Abu Suraya has ordered to remove the covering of the Abbasids and purify it, year one hundred and ninety-nine". Ibn Aftas used to attack the house of anybody who had a deposit (money) belonging to the Abbasid family; he would torture and harass them and impose penalties for their doings (Al-Zihbi 1989: XIII/78).

\section{5) The Revolt of Muhammad ibn Jafar Sadiq}

The time of Ma'mun also witnessed another uprising, which was different in origin and nature from other Alawi movements. Muhammad Dibaj, son of Imam Jafar Sadiq led this revolt in the year 816. People swore allegiance to him as Amir al-Mu'minin, and this instance tells us that he disobeyed Imam and did not follow him. During those days, the Abbasid government was facing tremendous unrest and did not pay attention to this revolt because they did not consider it a big threat, because it was confined only to Mecca and was easily confronted by the government forces, and Muhammad Dibaj was eventually forced to surrender.

Abul Faraj explains how this allegiance took place. He says: In the days of Abu Suraya, a person wrote a letter in Madina and in the letter, he disrespected Lady Fatimah, the daughter of the Prophet, and the rest of the Prophet's family. Muhammad Dibaj was not a public figure and never got involved in political issues. A group of people brought the letter to Muhammad and complained. Without replying to the letter, Muhammad went to his house and when he came out, he was in his armor, with a sword hanging from his neck. He called people to him and said: "My Lord knows I was not a person who would do such a thing. But today I'm burning with anger". Then, a group of people accompanied Muhammad ibn Jafar and went into battle with Haroon ibn Musayyab in Mecca, and Husain ibn Aftas, Muhammad ibn Sulayman ibn Dawood ibn Hasan ibn Hasan famous as-Saleeq, Ali ibn Husain ibn Zaid, Ali ibn Husain ibn Isa ibn Zaid and Ali ibn Jafar ibn Muhammad were amongst them. They fought fiercely killing many Haroon ibn Musayyab's people.

According to several historians, they defeated Haroon in the beginning. The Abbasid ruler pleaded with him in the name of Ali ibn Musa Ridha but Muhammad did not accept. This act shows that he was disobeying Imam Ridha. Later Haroon gathered a large army and Muhammad was surrounded; he ran out of food and water; as a result, he surrendered to Haroon in 816. 
Haroon sent him to Khurasan but, on the way there, a nomad caravan attacked Haroon's people and freed these Alawites and they themselves went to Hasan ibn Sahal, the governor of Baghdad.

Historians have a difference of opinion in the matter of his death. Some write that Hasan bin Sahal sent Muhammad ibn Jafar to Ma'mun. He died there, in Khurasan, and Ma'mun participated in his funeral procession. Others believe that Muhammad ibn Jafar Dibaj died in Jurjan and Ma'mun prayed in his funeral, and Muhammad Dibaj was buried there.

By studying these uprisings and rebellious movements by Alawites, one can easily understand that there was open enmity between Alawites and Abbasids. Abbasids used different means to stop the influence of Alawites. Abbasids were very cunning and deceitful, they sometimes showed their respect and friendship for Alawites, and many times used to forgive the rebels. This pardoning was not because of the concern for Alawites; rather it was a political move just to control the Alawi movements. For this reason, Ma'mun used to show his closeness to Alawites in order to confront any revolts in the future.

\section{Reasons behind the Revolts and Alawi Uprisings}

1) Alawites believed that it was the right of the children of Lady Fatimah to rule. The Umayyad and Abbasids dynasties were usurpers of this right.

2) The oppression and atrocities faced by the people, especially Alawites during the rule of Abbasids.

3) Social, individual, religious and political reasons were also involved in this case. This we can see in the revolt of Muhammad Dibaj when he saw the letter from an unknown person disrespecting Lady Fatimah Zahra. He was a silent and calm person, but he went to his house and came out ready to revolt and fight. In the revolt of Ibn Tabataba also, we see that continuous complaints of people against the government led to his revolt.

4) The belief and nature of fighting for rights against oppression and tyrants, which they inherited from their grandparents (the family of the Prophet).

\section{Reasons behind the Defeat of Alawi Revolts}

1) Disagreement of Imam Ridha with the leaders of these movements because they acted wrongly and against the rules of Islam. For example, we see that Ma'mun pardoned Zaid ibn Musa after his revolt for the sake of 
Imam; he just wanted to show people his concern for Alawites to gain political interests, but Imam strongly condemned his actions.

According to a narration, Imam swore that as long as he was alive he would never speak with Zaid. And he said to Zaid: "O' Zaid, have the people of Kufa made you feel superior when they say, because of the piety of Lady Fatimah Zahra Allah has refrained the fire of hell for the children of Fatimah. Do not forget it is only for Hasan and Husain who are born from her.

O' Zaid, if you think that after disobeying the Almighty you will get to heaven and your father Musa ibn Jafar after obeying Allah, praying during nights and fasting during the day, will enter heaven and you will be closer to Allah than you father, then absolutely you are wrong. Verily, no one will gain respect in the eyes of the Almighty unless by obeying his commands and you think you will reach those levels by disobeying him."

Zaid said: "I am your brother and I am the son of your father." Imam replied: "You are my brother only if you obey God." Then, Imam recited the verse of the holy Quran that talks about Prophet Noah and his son and said: "God abandoned the son of Noah because of his disobedience while he was from his family" (Qomi 2000: III/1580; Jazairi 2006: II/393; Qomi Mashhadi 1989: VI/180).

2) Absence of learned and dynamic leadership. No movement can become a success unless it is led by a well-informed leader. During these revolts led by Alawites, not only did they not have a good leadership, but sometimes the leaders did immoral things which made people leave the movement, and eventually they faced a bitter defeat.

3) The revolts were not organized and lacked unity. Most of these movements were exclusively for an area and they were not inclusive and general.

4) Lack of unity amongst the groups. Had they been united, they would have achieved their common goals.

5) Lack of planning and proper resources, not even having scholars who could plan out risk management. This sort of unplanned movements leaves these sacrifices and resources in vain.

6) Overcoming of sentiments over intellect, which is acceptable in religious sentiments but unacceptable in such movements and revolts. The revolts that took place during this time were usually based upon human sentiments and emotions and lacked proper intellectual backing. Therefore, either the leaders surrendered or the companions left them on their own. 
7) The government was not worried about external policies and wars and paid more attention to the internal situation.

8) Awareness of the government and acting quickly in controlling such uprisings against them. The longest revolt lasted for two months only.

9) The general belief amongst the rebels was that Imam should always be ready to revolt and fight. This thinking itself misled the Islamic society. Instead, Imam Ridha insisted on fighting against intellectual schools. Imam preferred taking cultural fights to armed conflicts because he knew that the result of such revolts was only facing a harsh defeat.

\section{The Reasons for Which Imam Did not Support These Revolts}

1) Lack of strong and reliable fellows.

2) The revolts were regional and without any strong management which compromised the identities of Shiites.

3) Weakness of the people, lack of capability and early defeats would lead to capture of Shiites and their execution by the government.

4) Immoral and unlawful deeds of the rebels, such as burning houses, burning enemies, killings, looting, etc. kept Imam away from them.

5) These revolts were not organized, which led to the disorder and insecurity of the society and people misused it.

6) The concept of Imamate was not clear for the people (that Imam was the one appointed by Allah himself); instead, their perception of Ahl al-Bayt was very common and of general sense. Alawites were not after their Imam, rather everybody claimed to be an Imam for himself. For example, Ibn Tabataba in Kufa, asked people for allegiance, a person who was recommended by the family of the Prophet, who would act according to the Book (Quran) and Tradition (Sunnah), and would call for right and stop from wrong and wrote a letter to Imam Ridha to accept his call. Likewise, Muhammad ibn Jafar Sadiq in Hijaz, called people for his Imamate and claimed to be Amir al-Mu'minin.

7) Imam Ridha believed in developing cultural aspects, and progress in belief and intellect. He wanted to spread the teachings of Allah, Prophet and 
Imam Ali ibn Abi Talib. He did not believe in armed conflicts because that was not the suitable time.

Keeping in mind the great position Shiites hold for the Imams, the issue of Imam's opinion regarding these revolts is more than just historical research. Because Imam's approval or disagreement for these revolts would form the fundamentals of religious judiciary and these views will be considered as political and jurisprudential principles in their lives.

After Imam Sajjad, political and social situation gradually changed, because after the tragedy of Karbala, the Shia community was extremely weakened. In general, every Imam took a different stand in their time, compatible with the situation in those days. Looking at these factors, Imam did not fully disapprove of these revolts nor did he approve of them. Imam partially accepted those movements that brought awareness to the people in order to oppose the oppressive regime. In practice, Imam's opinion was different from the leaders of these revolts. For instance, Imam did not argue with his brother Zaid on the origin of the revolt, and he never asked Zaid why he fought against the tyrant government! Rather, Imam was against unlawful ways and methods. We wrote Isfahani's words: "Zaid bin Musa Alawi was called Zaid al-Naar because he burned the houses of the members of the Abbasid family and their supporters in Basra. Moreover, whenever a person in black clothes (supporter of Abbasids) was brought to him, he would burn him alive" (Qomi 2000: II/377; Ibn Kathir 1988: X/246).

When Abu Suraya faced his defeat and fell back to Kufa, Muhammad ibn Muhammad Alawi and his followers attacked the houses of Abbasids and their supporters and forced them out of Kufa. They committed these inhumane acts and plundered the deposits that Abbasids kept safe with the people in Kufa. Likewise, Ibn Aftas in Madina confiscated the properties of Abbasids and tortured them. This is why Imam did not support them and knew the consequences.

Although the seventh Imam saw that Shahid Fakh was firm in his intention, while he knew that he would be defeated, Imam told him: even though you will be martyred, you stay firm in your way, and I pray for the best reward for you from the Almighty.

Imams concentrated on education and cultural activities and did not support armed revolts. For this reason, not only did they not participate in these anti-government movements, but they also stopped their followers from taking part in such activities, because he believed that these movements would harm the Shiites both in the short and long term. In the short term, because the Shiites and their worthy followers in different parts would be exposed and identified, and consequently martyred. In the long term, for 
the reason that the development of the Shia community would be halted for centuries and Imams would lose the opportunity for cultural development.

\section{Conclusion}

The objection to Imam's way of not supporting the revolts against the government is overruled because he analyzed the situation and knew that any movement against the regime would only result in a defeat and would bear no fruit for the Shiites. Imam tried to make the society more aware and worked hard on their upbringing and guidance. Imam Ridha did not fully approve of the revolts nor did he absolutely reject them. As long as these revolts helped in spreading awareness amongst people about oppressions of the government, Imam partially agreed to them. However, in practice, Imam's opinion was very different from the leaders of these revolts. During the time of Imam Ridha, these revolts had a great influence on the decisions of Ma'mun to the extent that Ma'mun was forced to invite Imam Ridha in his administration and make him the crown prince. Therefore, one of the results of these revolts was that it changed the policy of Abbasid government towards the position of Imamate, concerning their right in the administration and government.

Received: January $14^{\text {th }}, 2020$.

Accepted: April 29 2020.

\section{References}

The holy Quran.

Ali ibn Musa al-Ridha (1986), Sahifat al-Imam al-Ridha, edited by Muhammad Mahdi Najaf, Mashhad, The World Congress of Imam Ridha.

Al-Zihbi, Shamsuddin (1989), Tarikh al-Islam wa Wafayat al-Mashahir wa al$A^{\prime} l a m$, Beirut, Dar al-Kitab al-Arabi. $2^{\text {nd }}$ edition.

Fazlullah, Muhammad Jawad (2003), Tahlili az Zendeganiye Imam Ridha, translated by Sayyid Muhammad Sadiq Arif, Mashhad, Bonyade Pazhuheshhaye Eslamiye Astane Qodse Razavi, $7^{\text {th }}$ edition.

Hilali, Sulaym ibn Qays (1985), Kitabu Sulaym ibn Qays al-Hilali, edited by Muhammad Ansari Zanjani Khuini, Qom, al-Hadi.

Ibn al-Athir, Abu al-Hasan Ali ibn Muhammad (1965), al-Kamil fi at-Tarikh, Beirut, Dar as-Sadir.

Ibn Babiwayh, Muhammad ibn Ali (1999), Uyunu Akhbar ar-Ridha, edited by Mahdi Lajiwardi, Tehran, Nashre Jahan. 
Ibn Babiwayh, Muhammad ibn Ali (2006), Ilal al-Sharayi', Qom, Ketabforushiye Dawari.

Ibn Kathir, Abu al-Fida Imaduddin Ismail ibn Umar al-Dimashqi (1988), al-Bidaya wa al-Nihaya, edited by Ali Shiri, Beirut, Dar al-Fikr.

Ibn Mashhadi, Muhammad ibn Jafar (1998), Al-Mazar al-Kabir, edited by Jawad Qayyumi Isfahani, Qom, Jami'ah al-Mudarrisin.

Jazairi, Nimatullah ibn Abdullah (2006), Riyad al-Abrar fi Manaqib al-A'imma al-Athar, Beirut, Muassasa at-Tarikh al-Arabi.

Kulayni, Muhammad ibn Yaqub ibn Ishaq (1987), al-Kafi, edited by Ali Akbar Ghaffari and Muhammad Akhundi, Tehran, Dar al-Kutub al-Islamiyyah.

Majlisi, Muhammad Baqir ibn Muhammad Taqi (1983), Bihar al-Anwar, Beirut, Daru Ihya at-Turath al-Arabi.

Makarim Shirazi, Nasir (2001), Tafsire Nemune, Tehran, Dar al-Kutub al-Islamiyyah, $32^{\text {nd }}$ edition.

Qomi, Shaykh Abbas (2000), Muntaha al-Amal fi Tawarikh al-Nabiyy wa al-Al, Qom, Dalile Ma.

Qomi Mashhadi, Muhammad ibn Muhammad Ridha (1989), Tafsiru Kanz al-Daqaiq wa Bahr al-Gharaib, edited by Hossein Dargahi, Tehran, Sazmane Chap wa Entesharate Wezarate Farhang wa Ershade Eslami.

Saffar, Muhammad ibn Hasan (1984), Basair ad-Darajat fi Fazaili Ali Muhammad, edited by Muhsin ibn Abbas Ali Kuchebaghi, Qom, Maktabatu Ayatillah al-Mar'ashi al-Najafi.

Subhani Tabrizi, Jafar (2008), Risala Tawzih al-Masail, Qom, Muassasatu Imam al-Sadiq, $3^{\text {rd }}$ edition.

Tabari, Muhammab ibn Jarir (1967), Tarikh al-Umam wa al-Muluk, Beirut, Dar at-Turath, $2^{\text {nd }}$ edition. 


\title{
Političko delovanje imama Ride u kontekstu pobuna iz perioda njegovog života
}

\author{
Hamid-Reza Šodžaifard \\ Univerzitet za studije o religijama $i$ verskim pravcima, Kom, Iran
}

\section{Zahra Sadžadi}

Univerzitet za studije o religijama $i$ verskim pravcima, Kom, Iran

Imam je vodič, vođa i naslednik božjeg verovesnika na zemlji, što znači da njegove reči i dela predstavljaju za nas izvore religijskog autoriteta. Zapravo, imam predstavlja ljudima merilo u različitim aspektima njihovog religijskog života u sferama pojedinačnog, društvenog i političkog delovanja. Kao što imamove reči i dela analiziramo kao izvore saznanja iz oblasti religijskih doktrina i jurisprudencije, isto tako život imama predstavlja merilo političkog delovanja. Ako muslimanski i šiitski vernici žele da na tim poljima steknu večno blaženstvo, oni moraju slediti imame i u njihovom delovanju prepoznati osnovne smernice svog religijskog života.

Cilj ovog rada jeste da ispitamo političko delovanje imama Ride u kontekstu pobuna koje su izbile u periodu kada je bio imam i da u toj analizi reprodukujemo generalne modele muslimanskog političkog razmišljanja.

Ključne reči: bezgrešni imami, imam Rida, politika, islam, šiizam, delovanje, pobuna 